\title{
PENGOLAHAN TEMBAKAU DAN PEMBANGUNAN EKONOMI DI KABUPATEN PAMEKASAN
}

\author{
Mohammad Rofiuddin \\ Program Studi Magister Ilmu Ekonomi dan Studi Pembangunan \\ Fakultas Ekonomika dan Bisnis \\ Universitas Dipenogoro \\ E-mail:r4f155@gmail.com
}

\section{Tri Widayati}

Fakultas Ekonomika dan Bisnis Universitas 17 Agustus 1945 Semarang Email: triwiedy3@yahoo.com

\begin{abstract}
Abstrak
Pengolahan tembakau dan pembangunan ekonomi menjadi keterpaduan yang saling berkaitan. Peningkatan kontribusi pengelohan tembakau mempunyai multiplier effect baik pada kebutuhan tenaga kerja, jumlah produksi, produktivitas dan luas lahan. Pendekatan analisis yang digunakan dalam penelitian ini yaitu dengan deskripsi komparatif. Hasil penelitian menunjukkan bahwaKeseluruhan produksi tembakau di Kabupaten Pamekasan pada tahun 2013 sebesar 3.642 ton dan tahun 2014 sebesar 15.018 ton. Produktivitaspada tahun 2013 mencapai $431 \mathrm{~kg} / \mathrm{ha}$ dan tahun 2014 mencapai $446 \mathrm{~kg} / \mathrm{ha}$. Luas lahan pada tahun 2013 dan 2014 seluas 8.448 ha dan 26.905 ha. Pertumbuhanproduksi tembakau pada tahun 2014 di masing-masing kecamatan berkisar diantara 150 - 478 persen, produktivitas berkisar diantara $13-42$ persen danluas lahan berkisar diantara $104-216$ persen.Kontribusi pengolahan tembakau dalam setiap tahunnya terjadi fluktuasi.Pada tahun 2010 distribusi pengolahan lahan mencapai 1,97 persen, sedangkan pada tahun 2011 mencapai 1,92 persen. Distribusi terendah terjadi pada tahun 2013 yang mencapai 1,83 persen dan tahun 2014 mencapai 1,97 persen. Pertumbuhan pengelolahan tembakau pada tahun 2011 mencapai 3,29 persen. Pada tahun 2012 mengalami peningkatan yang mencapai 6,04 persen. pada tahun 2013 mengalami penurunan mencapai 1,54 persen dan pada tahun 2014 pertumbuhan pengelohaan tembakau mengalami kenaikan yang mencapai 13,49 persen, menunjukkan bahwa sektor pengolahan mengalami peningkatan. Pertumbuhan ekonomi Kabupaten Pamekasan pada tahn 2011-2014 dominan mengalami penurunan, namun masih berkisar antara angka 5 persen.
\end{abstract}

Kata Kunci: Pengolahan Tembakau, Produksi, dan Pembangunan Ekonomi.

\begin{abstract}
Tobacco processing and economic development become an interrelated integration. Increasing the contribution of tobacco processing has a multiplier effect on labor requirements, production quantity, productivity and land area. The analytical approach used in this research is with comparative description. The results showed that the overall production in Kabupaten Pamekasan in 2013 amounted to 3.642 ton and in 2014 amounted to 15.018 ton. Productivity in 2013 reached $431 \mathrm{~kg} / \mathrm{ha}$ and in 2014 reached $446 \mathrm{~kg} / \mathrm{ha}$. Land area in 2013 and 2014 covered 8.448 ha and 26.905 ha. Tobacco production growth in 2014 in each of sub-district ranged between 150-478 percent, productivity ranged between 13-42 percent and land area ranged between 104-216 percent. Fluctuation occurred in every year to the contribution of tobacco processing. In 2010 distribution of land processing reached
\end{abstract}


1.97 percent, while in 2011 reached 1.92 percent. Lowest distribution occurred in 2013 reached 1.83 percent and in 2014 reached 1.97 percent. Tobacco processing growth in 2011 reached 3.29 percent. In 2012 has increased that reached 6.04 percent. In 2013 has decreased amounted to 1.54 percent and in 2014 tobacco processing growth has increased that reached 13.49 percent, showed that tobacco processing sector has increased. Economic growth of Kabupaten Pamekasan in 2011-2014 dominantly has decreased, however it still ranges between 5 percent.

Keywords: Tobacco Processing, Production, Economic Development

\section{PENDAHULUAN}

Pembangunan ekonomi daerah menjadi suatu yag sangat penting dalam peningkatan kesejahteraan masyarakat serta menjadi tolak ukur perekonomian suatu daerah. Sehingga pertumbuhan ekonomi yang tinggi dan berkelanjutan merupakan kondisi utama atau suatu keharusan bagi kelangsungan pembangunan ekonomi dan peningkatan kesejahteraan. Pembangunan ekonomi daerah merupakan suatu proses dimana pemerintah daerah dan masyarakatnya mengelola sumber daya - sumber daya yang ada dan membentuk suatu pola kemitraan antara pemerintah daerah dengan sektor swasta untuk menciptakan suatu lapangan kerja baru dan merangsang perkembangan kegiatan ekonomi dalam wilayah tersebut (Arsyad, 2010).

Keberhasilan pembangunan ekonomi daerah dapat diukur dengan beberapa indikator yang lazim digunakan sebagai alat ukur. Salah satu indikator yang lazim digunakan adalah Produk Domestik Regional Bruto (PDRB) yang biasa menjadi petunjuk kinerja perekonomian secara umum sebagai ukuran kemajuan suatu daerah. Indikator lainnya adalah tingkat pertumbuhan, pendapatan perkapita dan pergeseran atau perubahan struktur ekonomi (Sjafrizal, 2008).

Pembangunan nasional dalam bidang ekonomi mempunyai sasaran utama terciptanya struktur ekonomi yang seimbang yaitu terdapat industri yang maju di dukung oleh sektor pertanian yang mantap (Wahyudi, 2008). Hal tersebut akan berguna dalam periode jangka panjang yang akan membawa suatu perubahan mendasar dalam struktur ekonomi, dari ekonomi tradisional ke ekonomi modern yang didominasi oleh sektor-sektor non-primer, khususnya industri pengolahan dengan increasing returns to scale yang dinamis sebagai mesin utama pertumbuhan.

Tembakau merupakan salah satu komoditas perkebunan yang penting di Indonesia. Produk utama dari tembakau yang banyak diperdagangkan adalah daun tembakau dan rokok. Industri tembakau di Indonesia berkembang dengan pesat sejalan dengan peningkatan jumlah perokok, hal ini berkaitan dengan kebiasaan merokok masyarakat Indonesia (Rachmat, 2010). Industri rokok yang semula hanya industri rumah tangga menjadi industri berskala besar nasional dan multinasional. Sejalan dengan itu industri rokok juga telah berperan dalam perekonomian nasional maupun daerah sebagai penyumbang penerimaan negaraatau daerah.

Tembakau Madura merupakan jenis tembakau yang mempunyai karakteristik dan keunikan tersendiri dibandingkan dengan jenis tembakau lainnya karena mempunyai aroma yang khas dan merupakan bahan baku utama bagi industri rokok kretek di samping cengkeh dan bahan-bahan lainnya. Industri rokok kretek dalam negeri yang besar merupakan pasar utama bagi tembakau 
Madura dan setiap pabrikan mempunyai standar kualitas yang berbeda-beda. Tapi secara umum, tembakau Madura yang dikembangkan oleh petani di lahan perkebunan rakyat merupakan tembakau yang banyak dibutuhkan oleh pabrikan rokok terutama pabrikan dalam negeri (Ambariyanto dan Herawati, 2010). Karena tembakau Madura memiliki keunggulan dari aromanya yang khas dan tembakau Madura tidak dapat dihasilkan di tempat lain, sekalipun bibitnya sama (Santoso, 2001).

Kabupaten Pamekasan yang merupakan salah satu kabupaten di Pulau Madura yang mayoritas penduduknya bermata pencaharian sebagai petani, sehingga sektor pertanian berperan penting dalam pertumbuhannya (Suprapti, 2010). Sehingga industri pengolahan tembakau juga akan ikut berkembangan. Tentu perkembangan indsutri tembakau juga akan berpenaruh terhadap pertumbuhan ekonomi. Adapun hasil pengelolahan tembakau dan produk domestik regional bruto Kabupaten pamekasan sebagaimana Tabel 1 .

Bedasarkan Tabel 1 menunjukkan bahwa subsektor industri pengolahan tembakau secara ablosut nilainya mengalami peningkatan dalam setiap tahunnya. Pada tahun 2010 nilainya sebesar Rp 138015,54 juta dan menjadi Rp 174188,30 juta pada tahun 2014. Begitu juga degan nilai produk domestik regional bruto yang pada tahun 2010 mencapai Rp 6994188,13 juta menjadi Rp 8856181,40 juta. Nilai tersebut mengidentifikasikan baik pengolahan tembakau dan produk domestik regional bruto sejalan. Artinya peningkatan pengolahaan tembakau akan diikuti produk domestik regional bruto di Kabupaten Pamekasan, selain penigkatan yang secara terus-menerus akan berpengaruh terhadap permintaan pertanian subsektor perkebunan tembakau meningkatkan.
Studi empiris yang dilakukan oleh Wahyudi (2008) menunjukkan bahwa sektor pertanian dan kelautan menjadi sektor yang berpontensi untuk dikembangkan. Khusunya perkebunan tembakau menjadi sektor cukup banyak tersebar dimasing-masing kecamatan di Kabupaten Pamekasan. Studi yang dilakukan Suprapti (2010), yang menunjukkan bahwa produksi tembakau diwilayah selatan Kabupaten Pamekasan memiliki potensi untuk dikembangkan dan tersebar diseluruh wilayah. Peningkatan disektor pertanian (tembakau) secara tidak langsung secara berkelanjutan akan berpengaruh terhadap industri pengolahan tembakau. Selain itu Kabupaten Pamekasan dalam rangka pengembangan Madura, kawasan andalannya yaitu sektor pertanian, perkebunan, industri, pariwisata, dan perikanan, pertambangan dan pariwisata (Pemda No. 16 tahun 2012). Sektor industri menjadi salah satu kawasan andalan mempunyai kontribusi yang cukup yaitu 5,93 pada tahun 2013 dan 6,04 pada tahun 2014.

Berdasarkan uraian di atas maka perlu dilakukan pengkajian terhadap kontribusi industri pengelohan tembakau, produksi dan produktivitas tembakau di Kabupaten Pamekasan dalam meningkatkan pertumbuhan ekonomi.

\section{KAJIAN PUSTAKA}

Menurut Kuncoro (2010) pembangunan ekonomi merupakan suatu proses multidimensional, karena pembangunan ekonomi bukan hanya bermakna perubahan dalam strukur ekonomi suatu negara yang diindikasikan oleh menurunnya peranan sektor pertanian dan meningkatnya peran sektor industri.Pembangunan ekonomi daerah didefinisikan sebagai suatu proses dimana pemerintah daerah dan masyarakatnya mengelola sumberdaya-sumberdaya yang ada dan membentuk suatu pola 
kemitraan antara pemerintah daerah dengan sektor swasta untuk menciptakan suatu lapangan kerja baru dan merangsang perkembangan kegiatan ekonomi dalam wilayah tersebut (Arsyad, 1999). Selain itu, pembangunan ekonomi daerah juga bisa diartikan sebagai suatu proses yang mencakup pembentukan institusi-institusi baru, pembangunan industri-industri alternatif, perbaikan kapasitas tenaga kerja yang ada untuk menghasilkan produk dan jasa yang lebih baik, identifikasi pasar-pasar baru, ilmu pengetahuan, dan perkembangan perusahaan-perusahaan baru.

\section{Teori Basis Ekonomi (Economic Base Theory)}

Menurut Teori basis ekonomi faktor penentu utama pertumbuhan ekonomi suatu daerah adalah permintaan akan barang dan jasa yang berasal dari luar daerah tersebut. Pertumbuhan industri yang menggunakan sumberdaya lokal, termasuk tenaga kerja dan bahan baku untuk ekspor, akan menghasilkan kekayaan daerah dan penciptaan peluang kerja (job creation). Model ini sangat berguna untuk menentukan keseimbangan antar jenis-jenis industri dan sektor yang dibutuhkan masyarakat untuk mengembangkan stabilitas ekonomi (Arsyad, 1999).

\section{Peranan Tembakau dan Industri Rokok dalam Perekonomian}

Sektor tembakau dan sektor industri rokok dapat dilihat peranannya dalam perekonomian nasional dari beberapa sisi, yaitu (1) sumber penerimaan negara (dari cukai); (2) pencipta devisa negara; (3) pencipta nilai output, nilai tambah, dan kesempatan kerja; (4) dampaknya terhadap sektor-sektor perekonomian lain (multiplier effect), dan (5) kaitannya dengan sektor hulunya (backward linkages) serta kaitannya dengan sektor hilirnya (forward linkages) (Hadi dan Friyatno, 2008).

\section{Produksi, Produktivitas dan Luas Lahan}

\section{Tembakau}

Dalam rangka meningkatkan kesejahteraan petani, berdasarkan Surat Edaran Gubernur Kepala Daerah Tingkat I Jawa Timur setiap tahun dikeluarkan Petunjuk Pelaksanaan Pembinaan Pertembakauan dan Program Intensifikasi Tembakau Virginia dan Intensifikasi Tembakau Rakyat di Jawa Timur. Petunjuk itu mengatur proyeksi luas lahan tanaman tembakau untuk tahun tersebut. Luas lahan tanaman tembakau disesuaikan dengan kebutuhantembakau pabrik rokok, sehingga diharapkan terjadi keseimbangan antara jumlah kebutuhan dengan jumlah produksi tembakau, yang akan berdampak positif memperbaiki harga tembakau dan tingkat pendapatan petani tembakau (Santoso, 2001).

\section{METODE PENELITIAN \\ Jenis dan Sumber Data}

Jenis data yang digunakan dalam penelitian ini adalah data sekunder berupa data kuantitatif yang meliputi data output pengolahan tembakau dan produk domestik regional bruto tahun 2010-2014. Sedangkan luas lahan, produksi tembakau, dan produktivitas pada tahun 2013-2014 di Kabupaten Pamekasandiperoleh dari data Badan Pusat Statistik

\section{Metode Analisis Data}

Metode yang digunakan dalam penelitian ini menggunakan pendekatan deskriptif komparatif. Deskriptif yaitu menganalisis data untuk permasalahan variabel-variabel mandiri. Sedangkan komparatif merupakan analisis data untuk membandingkan permasalahan suatu objek dengan objek lainnya (Juliandi,dkk. 2014). 
Adapun yang akan dikomparasi yaitu pada salah satu kinerja ekonomi tembakau dan kontribusi sektor-subsektor tehadap PDRB.

\section{Kinerja Ekonomi Tembakau}

Kinerja ekonomi tembakau dapat dilihat dari beberapa aspek, yaitu (1) perkembangan produksi, produktivitas dan luas lahan pertanian tembakau; (2) perkembangan jumlah industri pengolah berikut produksi dan penyerapan tenaga kerja; dan (3) sifat konsumsi produk tembakau (Hadi dan Friyatno, 2008). Dalam penelitian ini mendekatai hanya salah satu yang digunakan terutama pada poin (1).

\section{Kontribusi Sektor-Subsektor Ekonomi Terhadap PDRB}

Salah satu alat pengukur prestasi kegiatan ekonomi suatu daerah yaitu tingkat pendapatan regional, dalam konteks ini ditunjukkan oleh besaran Produk Domestik Regional Bruto(PDRB) baik yang ditunjukkan oleh PDRB atas dasar harga berlaku (ADHB) maupun atas dasar harga konstan (ADHK) (Wahyudi, 2008). Dari angka PDRB dapat diperoleh gambaran umum kontribusi, pertumbuhan ekonomi juga beberapa agregat pendapatan regional dalam lingkup wilayah Kabupaten Pemekasan.

\section{HASIL DAN PEMBAHASAN \\ Perkembangan Produksi, Produktivitas dan Luas Lahan}

Tembakau Madura khususnya di Kabupaten Pamekasan yang dibudidayakan oleh masyarakat mempunyai ciri khas, sehingga berdampak pada permintaan yang datang dari perusahaan-perusahaan rokok. Bahkan di Kabupaten Pamekasan gudang tembakau dari berbagai perusahaan kretek nasional tersedia. Dengan banyaknya permintaan baik dari dalam daerah maupun luar daerah mendorong masyarakat untuk membudidayakan tanaman tembakau. Hasil produksi, produktivitas dan luas lahan tembakau di Kabupaten Pamekasan pada 2013-2014 disajikan pada Tabel 2.

Tabel 2 menunjukkan bahwa di Kabupaten Pamekasan masing-masing kecamatan pada tahun 2013 dan 2014 secara absolut mengalami kenaikan produksi. Begitu juga dengan nilai produktivitas dan luas lahan juga mengalami peningkatan. Hal ini tentu dari sisi produksi berpengaruh terhadap permintaan tenaga kerja dan perluasan lahan yang lebih tinggi. Adapun nilai produksi dan lahan tertinggiada di Kecamatan Proppo yang memiliki nilai masing-masing produksi 2.150 ton dan lahan seluas 3.583 ha. Namun untuk produktivitas yang paling tinggi ada pada Kecamatan Pamekasan dan Pakong yang mencapai angka $620 \mathrm{~kg} / \mathrm{ha}$. Secara keseluruhan produksi tembakau Kabupaten Pamekasan pada tahun 2013 sebesar 3.642 ton dan tahun 2014 sebesar 15.018 ton, sedangkan produktivitasnya pada tahun 2013 mencapai $431 \mathrm{~kg} / \mathrm{ha}$ dan tahun 2014 mencapai 446 $\mathrm{kg} / \mathrm{ha}$, serta luas lahan pada tahun 2013 dan 2014 masing-masing seluas 8.448 ha dan 26.905 ha. Adapun pertumbuhan produksi, produktivitas dan luas lahan masing-masing kecamatan di Kabupaten Pamekasan dapat dilihat pada Tabel 3.

Tabel 3 menunjukkan bahwa pertumbuhan produksi, produktivitas dan luas lahan tembakau di Kabupaten Pamekasantahun 2014 meingkat. pertumbuhan produksi tembakau pada masing-masing kecamatan berkisar diantara $150-478$ persen, sedangkan produktivitas pertumbuhannya berkisar diantara 13 - 42 persen. Adapun pertumbuhan luas lahan berkisar diantara 104 - 216 persen. Besarnya pertumbuhan pada luas lahan akan mempunyai konsekuensi lain terhadap produksi perkebunan lainnya yaitu pengalihan 
pembudidayaan yang bukan pada kebiasaanya. Pertumbuhan produksi tertinggi terjadi pada Kecamatan Proppo sebesar 432,28 persen dan pertumbuhan produksi terendah pada Kecamatan Galis sebesar 150,57 persen.

Adapun pertumbuhan produktivitas tertinggi terjadi pada kecamatan Palengaan yang mencapai 41,03 persen dan terendah pada kecamatan Pamekasan yang mencapai 13,55 persen. Sedangkan pertumbuhan luas lahan tertinggi pada kecamatan Proppo yang mencapai 315,18 persen dan terendah terjadi pada kecamatan Pakong 154,32 persen. Secara grafik pertumbuhan produksi, produktivitas dan luas lahan disajikan pada Gambar 1.

Pada Gambar 1 terlihat bahwa peningkatan produksi, produktivitas dan pertumbuhan lahan tidak lepas karena komoditas itu memiliki peran yang penting. Fauziyah, et al. (2010) Tembakau merupakan salah satu komoditas perkebunan yang masih memiliki peranan cukup penting dalam pembangunan sub sektor perkebunan. Berbagai macam persoalan yang dihadapi oleh petani tembakau di Kabupaten Pamekasan tidak menyebabkan penurunan hasil produksi tembakau terhadap perekonomian Pamekasan. Hal tersebut menunjukkan bahwa perkebunan tembakau akan tetap eksis dan akan berdampak pula pada industri pengolahannya.

\section{Peran Tembakau Dalam Perekonomian di Kabupaten Pamekasan}

Terdapat lima kelompok industri pengolahan hasil tembakau di Indonesia, yaitu (1) industri pengeringan dan pengolahan tembakau dan bumbu rokok; (2) industri rokok kretek; (3) industri rokok putih; (4) industri rokok lainnya (cerutu, kelembak/menyan); dan (5) industri hasil lainnya dari tembakau, bumbu rokok, dan klobot/kawung (Hadi. dan Friyatno, 2008). Pada dasarnya peran tembakau dalam perekonomian nasional atau daerah dapat dilihat dari beberapa indikator yang meliputi subsektor perkebunantembakau dan juga dari industri pengolahan tembakau. Namun selain peran tersebut peran tembakau juga bisa lihat dari sumber lapangan kerja dan pendapatan masyarakat. Karena hampir dominan di Kabupaten Pamekasan petaninya menanam tembakau apabila musim tiba. Adapun Pada kontribusi pengelohan tembakau di Kabupaten Pamekasan pada tahun 2010-2014 dapat dilihat pada Tabel 4.

Tabel 4 menunjukkan terjadinya fluktuasi pada kontribusi atau peran pengolahan tembakau dalam setiap tahunnya terjadi fluktuasi. Pada tahun 2010 distribusi pengolahan lahan mencapai 1,97 persen namun mengalami penurunan pada tahun 2011 yang mencapai 1,92 persen. Distribusi terendah terjadi pada tahun 2013 yang mencapai 1,83 persen. Kecil kontribusi tidak lepas karena tembakau yang ada di Pulau Madura tidak sepenuh pengelohannya dilakukan daerah KabupatenPamekasan. Artinya multiplier effect akan sangat kecil. Namun melihat konsisten distribusi pengelolaan diindikasi menunjukkan bahwa industri pengolahan perlu dilakukan pengembangan agar mampu memberikan peran yang lebihtinggi.

Kontribusi pengolahan tembakau yang terbilang kecil, menunjukkan nilai pertumbuhan yang cenderung tidak konsiten. Pertumbuhan pengolahan tembakau tahun 2011 hanya mencapai 3,29 persen dan pada tahun 2012 pertumbuhannya mengalami peningkatan mencapai 6,04 persen. Namun pada tahun 2013 mengalami penurunan kembali yanghanya mencapai 1,54 persen. Kondisi ini memperlihatkan adanya ketidak konsistenan dalam pengolahan tembakau. Hal ini tidak bisa dipungkiri mengingat dari 
produksi tembakau, mulai dari penanaman sampai panen tergantung pada situasi dan kondisi. Terutama masalah musim yang berganti dan tidak kosisten akan sangat berpengaruh terhadap hasil panenyang pada akhirnya pengaruh terhadap pengelohan tembakau. Menariknya pada tahun 2014 pertumbuhan pengelohaan tembakau mengalami kenaikan yang mencapai 13,49 persen, yang menunjukkan bahwa sektor pengolahan mengalami peningkatan sekaligus menjadi indikator kesejahteraan bagi petani, khususnya petani tambakau. Adapun kondisi antara pertumbuhan pengolahan tembakau dan pertumbuhan ekonomi dapat dilihat pada Tabel 5.

Pertumbuhan ekonomi Kabupaten Pamekasan pada tahun 2011-2014 dominan mengalami penurun. Namun angka tersebut masih konsisten di atas angka 5 persen yang menunjukkan bahwa pertumbuhan yang ada di Kabupaten Pamekasan masih tinggi. Dilihat dari pertumbuhan antara pengolahan tembakau dan ekonomi menunjukkan suatu hal yang berbeda, artinya ada perbedaan yang sangat kontrak antara total keseluruh produk domestik regional bruto dengan pengolahan tembakau. Di satu sisi ada yang mengalami ketidak konsistenan, disisi lain adayang terus konsisten. Hal ini memberikan indikasi bahwa ada faktor yang lain yang mempunyai pertumbuhan yang lebih tinggi dari pada pengolaan tembakau. Adapun gambaran dari kontribusi dan pertumbuhan pengolahan tembakau serta pertumbuahan ekonomi dapat liha pada Gambar 2.

Gambar 2 menunjukkan bahwa pertumbuhan pengolahan tembakau mengalami penurunan cukup tajam pada tahun 2013, dan meningkat pada tahun 2014. Sedangkan pertumbuhan ekonomi dominan mengalami penurunan namun selisihya tidak berbeda jauh atau cukup konsisten. Sama halnya dengan kontribusi pengolahan tembakau yang cukup konsiten dalam setiap tahunnya, meski mengalami penurunan dan kenaikan.

Tabel 1. Pengelolahan Tembakau dan Produk Domestik Regional Bruto Kabupaten Pamekasan tahun 2010-2014 (juta rupiah)

\begin{tabular}{ccc}
\hline \multirow{2}{*}{ Tahun } & \multicolumn{2}{c}{ Industri/Kategori/Komoditi } \\
\cline { 2 - 3 } & Pengolahan Tembakau & PDRB \\
\hline 2010 & 138015,54 & 6994188,13 \\
\hline 2011 & 142550,93 & 7429359,45 \\
\hline 2012 & 151165,62 & 7894002,29 \\
\hline 2013 & 153489,18 & 8369613,22 \\
\hline 2014 & 174188,30 & 8856181,40
\end{tabular}

Sumber: Badan Pusat Statistik Kabupaten Pamekasan, 2016 (diolah) 
Tabel 2. Produksi, Produktivitas dan Luas lahan Tembakau di Kabupaten Pamekasan tahun 2013-2014

\begin{tabular}{|c|c|c|c|c|c|c|}
\hline \multirow{2}{*}{ Kecamatan } & \multicolumn{2}{|c|}{ Produksi (Ton) } & \multicolumn{2}{|c|}{ Produktivitas $(\mathrm{Kg} / \mathrm{Ha})$} & \multicolumn{2}{|c|}{ Luas lahan (Ha) } \\
\hline & 2013 & 2014 & 2013 & 2014 & 2013 & 2014 \\
\hline 01 Tlanakan & 164 & 504 & 465 & 550 & 352 & 916 \\
\hline 02 Pademawu & 346 & 1.720 & 483 & 600 & 716 & 2.866 \\
\hline 03 Galis & 297 & 745 & 490 & 600 & 607 & 1.242 \\
\hline 04 Larangan & 191 & 628 & 502 & 600 & 380 & 1.047 \\
\hline 05 Pamekasan & 186 & 576 & 546 & 620 & 340 & 929 \\
\hline 06 Proppo & 404 & 2.150 & 468 & 600 & 863 & 3.583 \\
\hline 07 Palengaan & 202 & 1.167 & 390 & 550 & 518 & 2.121 \\
\hline 08 Pegantenan & 381 & 1.413 & 401 & 550 & 951 & 2.569 \\
\hline 09 Kadur & 233 & 941 & 413 & 540 & 564 & 1.742 \\
\hline 10 Pakong & 219 & 766 & 451 & 620 & 486 & 1.236 \\
\hline 11 Waru & 383 & 1.503 & 386 & 520 & 991 & 2.891 \\
\hline 12 Batumarmar & 361 & 1.677 & 375 & 500 & 962 & 3.353 \\
\hline 13 Pasean & 276 & 1.229 & 384 & 510 & 718 & 2.410 \\
\hline Jumlah/Total & 3.642 & 15.018 & 431 & 558 & 8.448 & 26.905 \\
\hline
\end{tabular}

Sumber: Badan Pusat Statistik Kabupaten Pamekasan, 2016 (diolah)

Tabel 3. Pertumbuhan Produksi, Produktivitas dan Luas lahan Tembakau di Kabupaten Pamekasan pada tahun 2014 (persen)

\begin{tabular}{lrrr}
\hline Kecamatan & Produksi & Produktivitas & Luas lahan \\
\hline 01 Tlanakan & 207,76 & 18,28 & 160,23 \\
\hline 02 Pademawu & 397,28 & 24,22 & 300,28 \\
\hline 03 Galis & 150,57 & 22,45 & 104,61 \\
\hline 04 Larangan & 229,25 & 19,52 & 175,53 \\
\hline 05 Pamekasan & 210,33 & 13,55 & 173,24 \\
\hline 06 Proppo & 432,28 & 28,21 & 315,18 \\
\hline 07 Palengaan & 477,50 & 41,03 & 309,46 \\
\hline 08 Pegantenan & 270,46 & 37,16 & 170,14 \\
\hline 09 Kadur & 303,90 & 30,75 & 208,87 \\
\hline 10 Pakong & 249,60 & 37,47 & 154,32 \\
\hline 11 Waru & 293,02 & 34,72 & 191,73 \\
\hline 12 Batumarmar & 364,66 & 33,33 & 248,54 \\
\hline 13 Pasean & 345,81 & 32,81 & 235,65
\end{tabular}

Sumber: Badan Pusat Statistik Kabupaten Pamekasan, 2016 (diolah) 


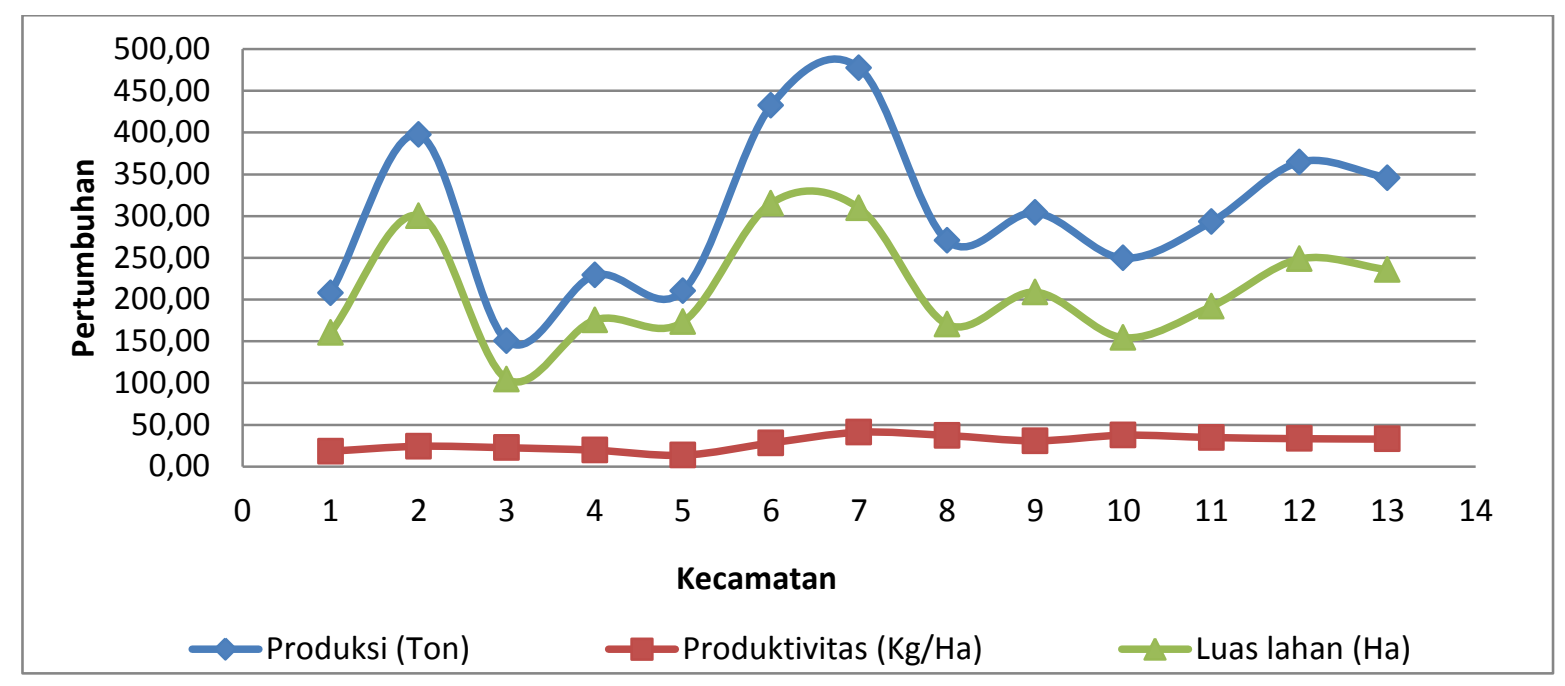

Sumber: Badan Pusat Statistik Kabupaten Pamekasan, 2016 (diolah)

Gambar 1. Pertumbuhan Produksi, Produktivitas dan Luas Lahan Kabupaten Pamekasan Tahun 2014

Tabel 4. Kontribusi Pengolahan Tembakau Terhadap Produk Domestik Regional Bruto di Kabupaten Pamekasan Tahun 2010-2014

\begin{tabular}{cccccc}
\hline Tahun & $\mathbf{2 0 1 0}$ & $\mathbf{2 0 1 1}$ & $\mathbf{2 0 1 2}$ & $\mathbf{2 0 1 3}$ & $\mathbf{2 0 1 4}$ \\
\hline Pengolahan Tembakau & 1,97 & 1,92 & 1,91 & 1,83 & 1,97 \\
\hline
\end{tabular}

Sumber: Badan Pusat Statistik Kabupaten Pamekasan, 2016 (diolah)

Tabel 5. Pertumbuhan Pengolahan Tembakau dan Pertumbuhan Ekonomi Kabupaten Pamekasan Tahun 2011-2014

\begin{tabular}{lrrrr}
\hline Uraian & $\mathbf{2 0 1 1}$ & $\mathbf{2 0 1 2}$ & $\mathbf{2 0 1 3}$ & \multicolumn{2}{c}{$\mathbf{2 0 1 4}$} \\
\hline Pertumbuhan Pengolahan Tembakau & 3,29 & 6,04 & 1,54 & 13,49 \\
\hline Pertumbuhan ekonomi & 6,22 & 6,25 & 6,02 & 5,81 \\
\hline
\end{tabular}

Sumber: Badan Pusat Statistik Kabupaten Pamekasan, 2016 (diolah)

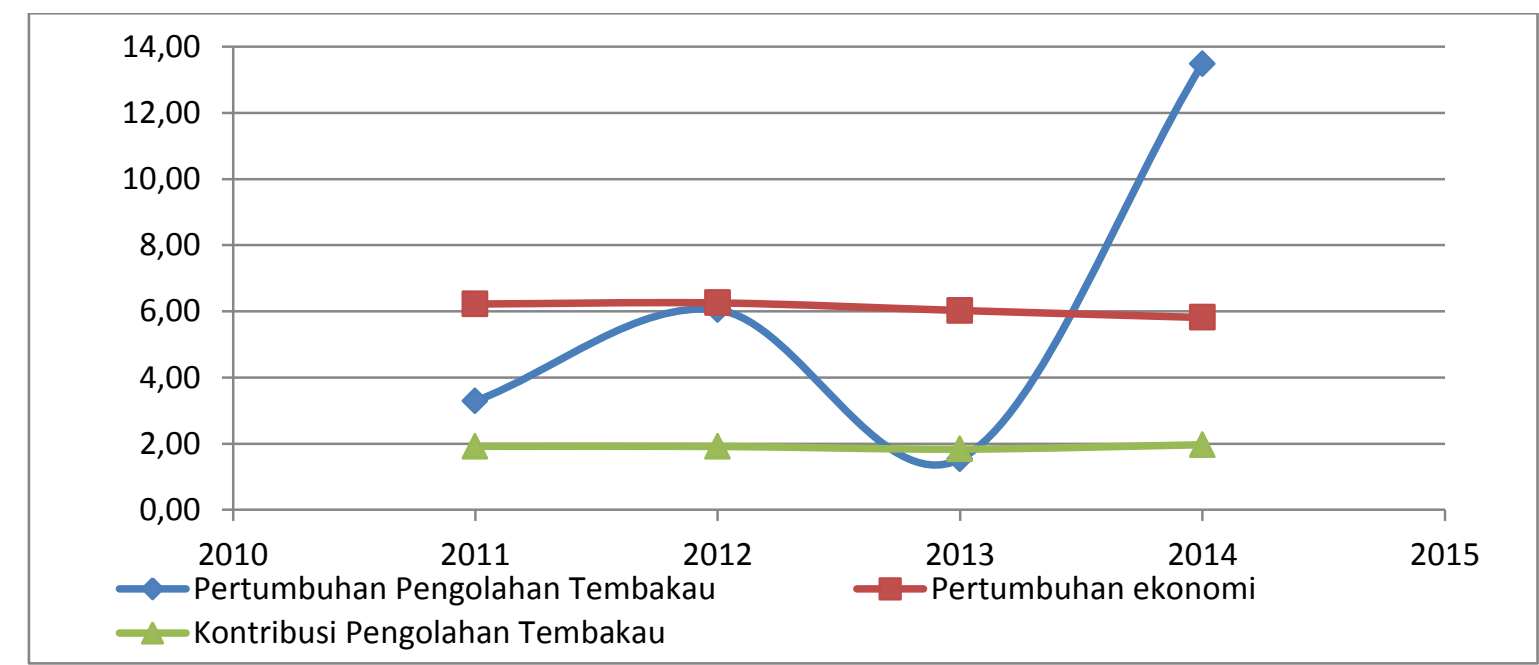

Sumber: Badan Pusat Statistik Kabupaten Pamekasan, 2016 (diolah)

Gambar 2. Kontribusi \& Pertumbuhan Pengolahan Tembakau dan Pertumbuahan Ekonomi Kabupaten Pamekasan tahun 2011-2014 


\section{PENUTUP}

\section{Kesimpulan}

Berdasarkan hasil analisis tentang tembakau dan pembangunan ekonomi di Kabupaten Pamekasan dapat disimpulkan bahwa:

1. Keseluruhan produksi tembakau Kabupaten Pamekasan pada tahun 2013 sebesar 3.642 ton dan tahun 2014 sebesar 15.018 ton, sedangkan produktivitasnya pada tahun 2013 mencapai $431 \mathrm{~kg} / \mathrm{ha}$ dan tahun 2014 mencapai $446 \mathrm{~kg} / \mathrm{ha}$, serta luas lahan pada tahun 2013 seluas 8.448 ha dan pada tahun 2014 seluas 26.905 ha.

2. Pertumbuhan produksi tembakau pada tahun 2014 di masing-masing kecamatan berkisar diantara $150-478$ persen, sedangkan produktivitas pertumbuhannya berkisar diantara 13 42 persen. Adapun pertumbuhan luar lahan berkisar diantara $104-216$ persen.

3. Pertumbuhan produksi tertinggi terjadi pada tahun 2014 Kecamatan Proppo yang mencapai 432,28 persen dan terendah pada kecamatan Galis yang mencapai 150,57persen. Pertumbuhan produktivitas tertinggi adalah Kecamatan Palengaan yang mencapai 41,03 persen dan pertumbuhan produktivitas terendah pada Kecamatan Pamekasan yang mencapai 13,55 persen. Sedangkan pertumbuhan luas lahan tertinggi pada kecamatan Proppo yang mencapai 315,18 persen dan terendah terjadi pada kecamatan Pakong 154,32 persen.

4. Kontribusi pengolahan tembakau dalam setiap tahunnya terjadi fluktuasi. Pada tahun 2010 distribusi pengolahan lahan mencapai 1,97 persen, pada tahun 2011 yang mencapai 1,92 persen. Distribusi terendah terjadi pada tahun 2013 yang mencapai 1,83 persen dan tahun 2014 mencapai 1,97 persen.

5. Pertumbuhan pengelolahan tembakau pada tahun 2011 mencapai 3,29 persen. Pada tahun 2012 mengalami peningkatan yang mencapai 6,04 persen. Namun pada tahun 2013 mengalami penurunan kembali yang hanya mencapai 1,54 persen. Sedangkan pada tahun 2014 pertumbuhan pengelohaan tembakau mengalami kenaikan yang mencapai 13,49 persen, menunjukkan bahwa sektor pengolahan mengalami peningkatan.

6. Pertumbuhan ekonomi Kabupaten Pamekasan pada tahn 2011-2014 dominan mengalami penurunan. Namun angka tersebut masih konsisten di atas angka 5 persen yang menunjukkan bahwa pertumbuhan yang ada di Kabupaten Pamekasan masih tinggi.

\section{Saran}

Berdasarkan hasil kesimpulan hasil pembangunan ekonomi Kabupaten Pamekasan dapat disarankan bahwa

1. Bagi pemerintah daerah Kabupaten Pamekasan khususnya Badan Perencanaan Pembangunan Daerah supaya tetap mempertahankan agar lebih konsen pada industri pengolahan tembakau, karena hal berpotensi untuk berkembang dan mempunyai multiplier efek.

2. Bagi dinas pertanian agar memperhatikan produksi dan lahan untuk tembakau, karena pengalihan lahan terhadap tanaman tembakau akan berpontesi pada produksi perkebunan lainnya. Selain itu hasil yang tembakau melimpah agar pengolahan diarahkan untuk dikelola di daerah asal. Hal tersebut akan berpotensi menciptakan permintaan tenaga kerja baru yang pada akhirnya 
berpengaruh pada pertumbuhan ekonomi.

\section{Ucapan Terima Kasih}

Peneliti mengucapkan terima kasih kepada Lembaga Pengelola Dana Pendidikan (LPDP) sebagai pemberi beasiswa pendidikan yang sungguh bermanfaat pada seluruh rangkaian studi dan publikasi penelitian ini.

\section{DAFTAR PUSTAKA}

Ambariyanto \& Herawati, N. (2010). Pengembangan Kelembagaan Pemasaran Komoditas Tembakau Terhadap Kesejahteraan Petani Di Kabupaten Sumenep. Jurnal Akuntansi, Manajemen Bisnis Dan Sektor Publik. $7(I), 21-45$.

Arsyad, L. (1999). Pengantar Perencanaan dan Pembangunan Ekonomi Daerah. Yogyakarta: BPFE.

Arsyad, L. (2010). Ekonomi Pembangunan. Yogyakarta: UPP STIM YKPN.

Badan Pusat Statistik. (2015). Produk Domestik Regional Bruto Kabupaten Pamekasan Menurut Lapangan Usaha Tahun 2010-2014. Pamekasan: BPS Kabupaten Pamekasan.

Badan Pusat Statistik. (2016). Kabupaten Pamekasan Dalam Angka Tahun 2005. Pamekasan: BPS Kabupaten Pamekasan.

Fauziyah, E.,Hartoyo, S., Kusnadi, N., \& Kuntjoro, S. U. (2013). Analisis Produktivitas Usahatani Tembakau Di Kabupaten Pamekasan. Jurnal Organisasi dan Manajemen, (6)2, 119131.

Hadi, P.U. \& Friyatno, S. (2016). Peranan Sektor Tembakau Dan Industri Rokok Dalam Perekonomian Indonesia: Analisis Tabel 1-0 Tahun 2000 Jurnal Agro Ekonomi, 26(1), 90-121.
Juliandi, A. \& Irfan, M. S.(2014). Metode Penelitian Bisnis: Konsep dan Aplikasi. Medan: UMSU Press.

Kuncoro, M. (2010). Dasar-Dasar Ekonomi Pembangunan. Yogyakarta: UPP STIM YKPN.

Peraturan Daerah Kabupaten Pamekasan No. 16 tahun 2012, Tentang Tata Ruang Wilayah Kabupaten Pamekasan 20122032.

Rachmat, M. (2010). Pengembangan Ekonomi Tembakau Nasional: Kebijakan Negara Maju Dan Pembelajaran Bagi Indonesia. Analisis Kebijakan Pertanian, 8(1), 67-83.

Santoso, T. (2001). Tata Niaga Tembakau di Madura. Jurnal Manajemen \& Kewirausahaan, 3(2), 96-105.

Sjafrizal. (2008). Ekonomi Regional, Teori dan Aplikasi. Padang: Baduose Media.

Suprapti, I. (2010). Analisis Ekonomi Regional Komoditas Tembakau Di Kabupaten Pamekasan. EMBRYO, 7(1), 8-14.

Wahyudi, S. T. (2008). Penguatan sektorSubsektor Ekonomi Dalam Upaya Peningkatan Pembangunan Ekonomi Daerah. Journal of Indonesian Applied Economics, 2(1),22-42. 